publicados innumeros trabalhos a elle attinentes e é, muito justamente, considerado uma das autoridades brasileiras no que se refere á lepra.

Além de scientista notavel, caracteriza-se o prof. Aguiar Pupo por suas qualidades de justiça e de bondade; é considerado nos meios academicos com as honras a que tem direito a sua personalidade individualissima.

A elle muito deve o Centro Academico "Oswaldo Cruz", que ha muito se aproveita da sua extraordinaria dedicação como chefe clinico do serviço de syphilis.

\title{
Sociedade Beneficiente "Arnaldo Vieira de Carvalho"
}

\section{EM TORNO DE UMA GRANDE OBRA}

Um dos assumptos palpitantes e que mais prende a attenção da classe academica de São Paulo é certamente aquelle que diz respeito á Sociedade Beneficiente "Dr. Arnaldo Vieira de Carvalho".

Producto de um trabalho fecundo, aquella sociedade representa, na sua plenitude, o esforço de um trabalhador e de um idealista - Sebastião de Paes e Alcantara.

Medito no momento o programma director d'aquella casa e prevejo o seu brilhantissimo futuro.

Creada nos moldes de uma existente no Rio de Janeiro, muito nova ainda, já está em condições de attender seus associados.

A sociedade que leva o nome do mestre e fundador da nossa Faculdade de Medicina tem, com criterio, efficiencia e rigorosa discreção, servido os que della se approximam.

Não se póde duvidar do exito da empreitada que tem á frente homens dedicados e retemperados no culto da energia como o são os directores da nova sociedade.

Lançando a idéa e posteriormente creando a "Caixa Beneficiente" Alcantara e seus infatigaveis companheiros agiram com serenidade, pondo acima de tudo, a centelha viva das aspirações academicas.

Nesta hora em que se manifesta o interesse pela grandeza e prosperidade desta instituição, ha como que uma esperança radiosa a consolar o coração, porque ella, irmanada ao desejo commum de collaborar pela finalisação dos ideaes da classe, trabalhará em pról de seu aperfeiçoamento material e moral, e, ás braçadas vigorosas levantará o magno problema da "Casa do Estudante", que tem sido o sonho acariciador, não só dos academicos Paulistas, como os de todos os outros Estados da União.

Assim é que, digna de todo o louvor, acatamento e apoio, a Sociedade Beneficiente "Arnaldo Vieira de Carvalho" representa o padrão de glorias de que se orgulha a actual geração academica. 